\title{
Selective exocytosis of zymogen granules induces non-parallel secretion in short-term cholecystokinin-stimulated rats
}

\author{
I de Dios ${ }^{1}$, A C Garcia-Montero' ${ }^{1}$, A Orfao ${ }^{2}$ and M A Manso' \\ ${ }^{1}$ Department of Physiology and Pharmacology, University of Salamanca, 37007 Salamanca, Spain \\ ${ }^{2}$ Flow Cytometry Service, University of Salamanca, 37007 Salamanca, Spain \\ (Requests for offprints should be addressed to I de Dios, Departamento de Fisiologia y Farmacologia, Edificio Departamental, Campus Miguel de Unamuno, \\ 37007 Salamanca, Spain; Email: bel@gugu.usal.es)
}

\begin{abstract}
Parallel studies on pancreatic enzyme secretion and zymogen granule enzyme composition have been carried out in rats subjected to infusion of cholecystokinin (CCK) $(1 \cdot 25 \mu \mathrm{g} / \mathrm{kg}$ per h) over $30 \mathrm{~min}$. Flow cytometric analysis showed a significant decrease in the mean value of granule size after CCK stimulation. The amount of trypsinogen stored in each individual zymogen granule was significantly lower at $30 \mathrm{~min}$ of CCK infusion, but no variation in intragranular amylase content was observed. As a result, the amylase/trypsinogen ratio was significantly increased in the zymogen granules that remained in the pancreas of
\end{abstract}

rats stimulated with $\mathrm{CCK}$ for $30 \mathrm{~min}$. A significantly greater proportion of trypsin than amylase was secreted after $30 \mathrm{~min}$ CCK infusion. Our results support the existence of different types of granules loaded with different proportions of enzymes. We conclude that short-term CCK stimulation induces the selective release of large granules containing a high proportion of trypsinogen, which leads to a non-parallelism of enzyme secretion.

Journal of Endocrinology (1999) 163, 199-206

\section{Introduction}

Cholecystokinin (CCK) is a gastrointestinal hormone that has a key integrative role in nutrient digestion and assimilation (Rehfeld 1989). Among other effects, CCK regulates the exocrine pancreatic function, and its major action on acinar cells is to stimulate digestive enzyme secretion (Williams \& Yule 1993). Under some conditions (Dagorn 1978, Grendell et al. 1984, de Dios et al. 1997b), the proportion of different enzymes is 'non-parallel'. A selective exocytosis of zymogen granules with different enzyme content has been suggested (Adelson \& Miller 1989), however, the mechanism for this phenomenon is still not completely understood. To prove the existence of different types of granules, it is necessary to measure the enzyme content in individual zymogen granules. Flow cytometry has proved to be a rapid, objective, sensitive and quantitative method for the analysis of a large number of individual granules of rat pancreas under different physiological, pharmacological and pathological conditions (de Dios et al. 1995, 1997b, Garcia-Montero et al. 1995, Manso et al. 1997, 1998, Rodriguez et al. 1997). The storage of enzymes in the pancreas represents the intermediate stage between synthesis and secretion, and consequently the understanding of this process is the key to assessing the different pancreatic responses to specific stimuli; nevertheless, little is known about it. In the present study, we have analysed the distribution patterns of amylase and trypsinogen in individual zymogen granules, together with the enzyme composition of pancreatic juice, in rats subjected to a CCK infusion over $30 \mathrm{~min}$, with the aim of finding out whether short-term CCK stimulation induces a selective release of different types of granules.

\section{Materials and Methods}

\section{Chemicals}

Sucrose, $\mathrm{MgSO}_{4}$, starch, potassium sodium tartrate and 3-5-dinitrosalicylic acid were from Merck (Darmstadt, Germany); maltose, bovine trypsin type III, $N$ - $\alpha$-benzoyl L-arginine- $p$-nitroaniline (BAPNA), ethylene glycolbis-(b-aminoethyl ether) $N, N, N^{\prime}, N^{\prime}$-tetra-acetic acid (EGTA), 3-(N-morpholino) propanesulphonic acid (MOPS), phenylmethylsulphonil fluoride (PMSF), 2-(Nmorpholino) ethanesulphonic acid (MES), Percoll, bovine serum albumin (BSA), CCK-8 (98\% purity) and rabbit anti-amylase antiserum were purchased from Sigma Chemical Company (St Louis, MO, USA); rabbit antitrypsinogen antiserum was obtained in our laboratory as previously described (de Dios et al. 1997b) and goat anti-rabbit immunoglobulin $G$ antiserum was from Caltag (Burlingame, CA, USA). 


\section{Animals and treatments}

Male Wistar rats weighing about $250 \mathrm{~g}$ were used. A standard laboratory diet (Panlab, rat chow) and water were available ad libitum. The rats were maintained at $24^{\circ} \mathrm{C}$ on a $12 \mathrm{~h}$ light : $12 \mathrm{~h}$ darkness cycle. Three groups of animals were randomly established:

Group 1 (controls): Rats that received an intravenous infusion of saline solution containing $0 \cdot 2 \%$ BSA over 15 min.

Group 2: Rats that received an intravenous infusion of saline solution containing $0 \cdot 2 \%$ BSA over $15 \mathrm{~min}$ and thereafter CCK-8 $(1 \cdot 25 \mu \mathrm{g} / \mathrm{kg}$ per h) resuspended in saline plus $0 \cdot 2 \%$ BSA for $5 \mathrm{~min}$.

Group 3: Rats that received an intravenous infusion of saline plus $0 \cdot 2 \%$ BSA over $15 \mathrm{~min}$ and thereafter CCK-8 $(1.25 \mu \mathrm{g} / \mathrm{kg}$ per $\mathrm{h})$ resuspended in saline plus $0 \cdot 2 \%$ BSA for $30 \mathrm{~min}$.

\section{Analysis of zymogen granules}

Isolation of zymogen granules Zymogen granules were isolated from the pancreas of control rats (group 1), considered to represent basal conditions, and of CCKinfused rats (groups 2 and 3) after pancreatic juice had been collected. For each experiment, pancreata of two rats were pooled and put on ice-cold homogenization medium $\mathrm{pH} 6.5$ containing $250 \mathrm{mM}$ sucrose, $5 \mathrm{mM}$ MOPS, $0.1 \mathrm{mM} \mathrm{MgSO}_{4}$ and $0.1 \mathrm{mM} \mathrm{PMSF}$ at $40 \mathrm{ml} / \mathrm{g}$ wet weight pancreas. They were finely minced with scissors and homogenized for $30 \mathrm{~s}$ in an electric homogenizer (Omni 2000 International) at low speed. Heavy components were removed by centrifugation at low speed. Zymogen granules were isolated according to the method of De Lisle et al. (1984) by centrifuging at $100000 \boldsymbol{g}$ for $20 \mathrm{~min}$ in a $40 \%$ Percoll gradient composed of a homogenization buffer, pH 5.5 (250 mM sucrose, $50 \mathrm{mM}$ MES, $0 \cdot 1 \mathrm{mM} \mathrm{MgSO}_{4}, 0 \cdot 1 \mathrm{mM}$ PMSF and $2 \mathrm{mM}$ EGTA) mixed with Percoll. Finally, the granules were washed twice (1300 g, $15 \mathrm{~min})$ with buffer $\mathrm{pH}$ 6.5 (0.3 M sucrose, $0 \cdot 1 \mathrm{mM} \mathrm{MgSO}, 2$ mM MOPS, $1 \mathrm{mM}$ EGTA).

Measurements of amylase and trypsinogen in zymogen granules Specific intragranular staining was carried out according to methods previously reported (de Dios et al. 1995, 1997b). Briefly, zymogen granules were incubated for $15 \mathrm{~min}$ with rabbit anti-amylase antiserum $(0.7 \mu \mathrm{g} / \mu \mathrm{l})$ or with rabbit anti-trypsinogen antiserum $(1 \mu \mathrm{g} / \mu \mathrm{l})$. The unbound antisera were removed by centrifuging twice in buffer $(2 \times 1300 \boldsymbol{g}$ for $15 \mathrm{~min})$. The pellet was resuspended and incubated in the dark for $15 \mathrm{~min}$ with goat anti-rabbit immunoglobulin antiserum labelled with phycoerythrin $\left(1 \times 10^{-2} \mu \mathrm{g} / \mu \mathrm{l}\right)$. To remove the unbound antiserum, centrifugation medium was added twice $(2 \times 1300 \mathrm{~g}$ for $15 \mathrm{~min})$. Neither selective nor significant loss of the enzymes was observed in the
Table 1 Enzyme activity in the supernatants before and after incubating zymogen granules with specific antisera. Values are means \pm S.E.M.; $n=$ number of experiments

\begin{tabular}{llll} 
& $\begin{array}{l}\text { Before primary } \\
\text { antiserum }\end{array}$ & $\begin{array}{l}\text { After secondary } \\
\text { antiserum }\end{array}$ \\
\cline { 2 - 2 } $\begin{array}{lll}\text { Amylase } \\
(\mathrm{U} / \mathrm{ml})\end{array}$ & $\begin{array}{l}0 \cdot 052 \pm 0 \cdot 02 \\
(n=5)\end{array}$ & $\begin{array}{l}0 \cdot 041 \pm 0 \cdot 014 \\
(n=5)\end{array}$ \\
$\begin{array}{l}\text { Trypsin } \\
(\mathrm{U} / \mathrm{ml})\end{array}$ & $\begin{array}{l}0 \cdot 016 \pm 0 \cdot 006 \\
(n=5)\end{array}$ & $\begin{array}{l}0 \cdot 012 \pm 0 \cdot 04 \\
(n=5)\end{array}$
\end{tabular}

supernatants of the centrifugation steps during preparation for flow cytometry (Table 1). Flow cytometric measurement of intragranular enzyme content had previously been validated with biochemical assays of enzyme activity (de Dios et al. 1997b).

Flow cytometric analysis of zymogen granules All flow cytometric measurements of zymogen granules were performed for at least 10000 events per test in each experiment. A FACScan flow cytometer (Becton/ Dickinson, San José, CA, USA) equipped with an argon ion laser set at $488 \mathrm{~nm}$ and $15 \mathrm{~mW}$ was used, as we have described previously (de Dios et al. 1995, 1997a,b, Garcia-Montero et al. 1995, Manso et al. 1997, 1998). Sample (medium washing)/sheath (FACS flow, Becton/Dickinson) differential pressure was set at low speed in order to obtain a minimum diameter of the sample part of the flow at the intersection of the laser beam. During the entire measurement process, the zymogen granules remained suspended in the washing buffer, which was surrounded by the sheath fluid, and no admixture occurred between the two fluids, in accordance with the principles of FACScan flow cytometer analysis (Kachel et al. 1990). Calibration of the instrument was performed on a daily basis using Calibrite beads (Becton/ Dickinson). Fine adjustments were performed using unstained zymogen granules and fluorescence compensation was established by measuring anti-amylase- or antitrypsinogen-stained zymogen granules. Each day, zymogen granules from CCK-infused and control rats were measured in parallel. The Lysis II software program was used for data acquisition and analysis; in each experiment, the mean value per individual zymogen granule was calculated using this software. Results were expressed as the mean value of at least five experiments.

\section{Study of pancreatic secretion}

Collection of pancreatic juice Rats were anaesthetized with sodium pentobarbitone $(3 \mathrm{mg} / 100 \mathrm{~g}$ body weight, i.p.). After tracheotomy, a median laparotomy was performed, the bile duct was cannulated at its exit from the liver to divert bile flow to the exterior, and the pancreatic bile duct was cannulated at its exit into the duodenum, to collect pure pancreatic juice. The jugular vein was 
catheterized for infusion of $0 \cdot 15 \mathrm{M} \mathrm{NaCl}$ containing $0 \cdot 2 \%$ BSA over $15 \mathrm{~min}$, considered as the basal period, and for infusion of $1.25 \mu \mathrm{g} / \mathrm{kg}$ per $\mathrm{h}$ CCK-8 resuspended in $0 \cdot 15 \mathrm{M} \mathrm{NaCl}$ containing $0 \cdot 2 \% \mathrm{BSA}$ over $5 \mathrm{~min}$ (group 2) or $30 \mathrm{~min}$ (group 3) thereafter. Infusion was carried out with a peristaltic pump (LKB, model 2132) at a flow rate of $0.5 \mathrm{ml} / \mathrm{h}$.

The animals were unconscious during the entire period of juice collection, and body temperature was kept at $37 \pm 1{ }^{\circ} \mathrm{C}$ by placing the rats on a heating pad and monitoring rectal temperature with a thermometer. Pancreatic juice was collected in pre-weighed Eppendorf tubes on ice, to preserve the enzyme content.

Finally, the pancreas was quickly removed and freed from fat and lymph nodes for the isolation of zymogen granules.

Biochemical assays Pancreatic juice volume was estimated by direct weighing on an electronic balance, assuming the density of the juice to be $1 \cdot 0 \mathrm{~g} / \mathrm{ml}$. According to the method of Noelting \& Bernfeld (1948), amylase activity in pancreatic juice was determined immediately as follows. A solution of $2 \%$ of starch (w/v) in $0.02 \mathrm{M}$ saline phosphate buffer was used as a substrate, and $100 \mu \mathrm{l}$ pancreatic juice containing $100 \mu \mathrm{g} / \mu \mathrm{l}$ protein was incubated with $5 \mathrm{ml}$ of this starch solution at $38^{\circ} \mathrm{C}$ for $5 \mathrm{~min}$. The maltose produced as a result of enzymic action was quantified by the addition of a solution containing $0.02 \mathrm{M}$ 3-5-dinitrosalicylic acid, $0.1 \mathrm{M} \mathrm{NaOH}$ and $0.4 \mathrm{M}$ potassium sodium tartrate, in a ratio of $1: 5(\mathrm{v} / \mathrm{v})$, incubation at $100{ }^{\circ} \mathrm{C}$ for $10 \mathrm{~min}$, dilution with water in a ratio of $1: 10$ (v/v), and measurement at $520 \mathrm{~nm}$. Maltose spontaneously released was measured from a tube containing $2 \%$ starch, but without pancreatic juice, and subjected to the same reaction conditions; the absorbance value was subtracted from the values obtained in the tubes with pancreatic juice. The amount of amylase in pancreatic juice was calculated by comparison with a standard curve, using known concentrations of maltose.

The measurement of trypsin activity was carried out by the method of Caldwell \& Sparrow (1970) modified by Manso et al. (1992). Pancreatic juice diluted to a protein concentration of $100 \mu \mathrm{g} / \mathrm{ml}$ was incubated during $24 \mathrm{~h}$ at $4{ }^{\circ} \mathrm{C}$ with a solution of bovine trypsin type III $(25 \mu \mathrm{g} / \mathrm{ml})$ in $0.01 \mathrm{M}$ Tris- $\mathrm{HCl}$ buffer, $\mathrm{pH} 7 \cdot 6$ containing $0.05 \mathrm{M}$ $\mathrm{CaCl}_{2}$, in order to activate the trypsinogen. BAPNA $(0 \cdot 2 \mathrm{M})$ in Tris- $\mathrm{HCl}$ buffer was used as a substrate, and $100 \mu$ activated pancreatic juice was incubated with $2.4 \mathrm{ml}$ of this BAPNA at $37^{\circ} \mathrm{C}$ for $20 \mathrm{~min}$. The reaction was halted by the addition of $500 \mu 120 \%$ acetic acid, and $p$-nitroaniline was measured at $410 \mathrm{~nm}$, as a product of the enzyme reaction. The absorbance obtained from a tube containing $25 \mu \mathrm{g} / \mathrm{ml}$ bovine trypsin was subtracted. Trypsin activity in pancreatic juice was calculated by extrapolation with a standard curve, using known concentrations of bovine trypsin.
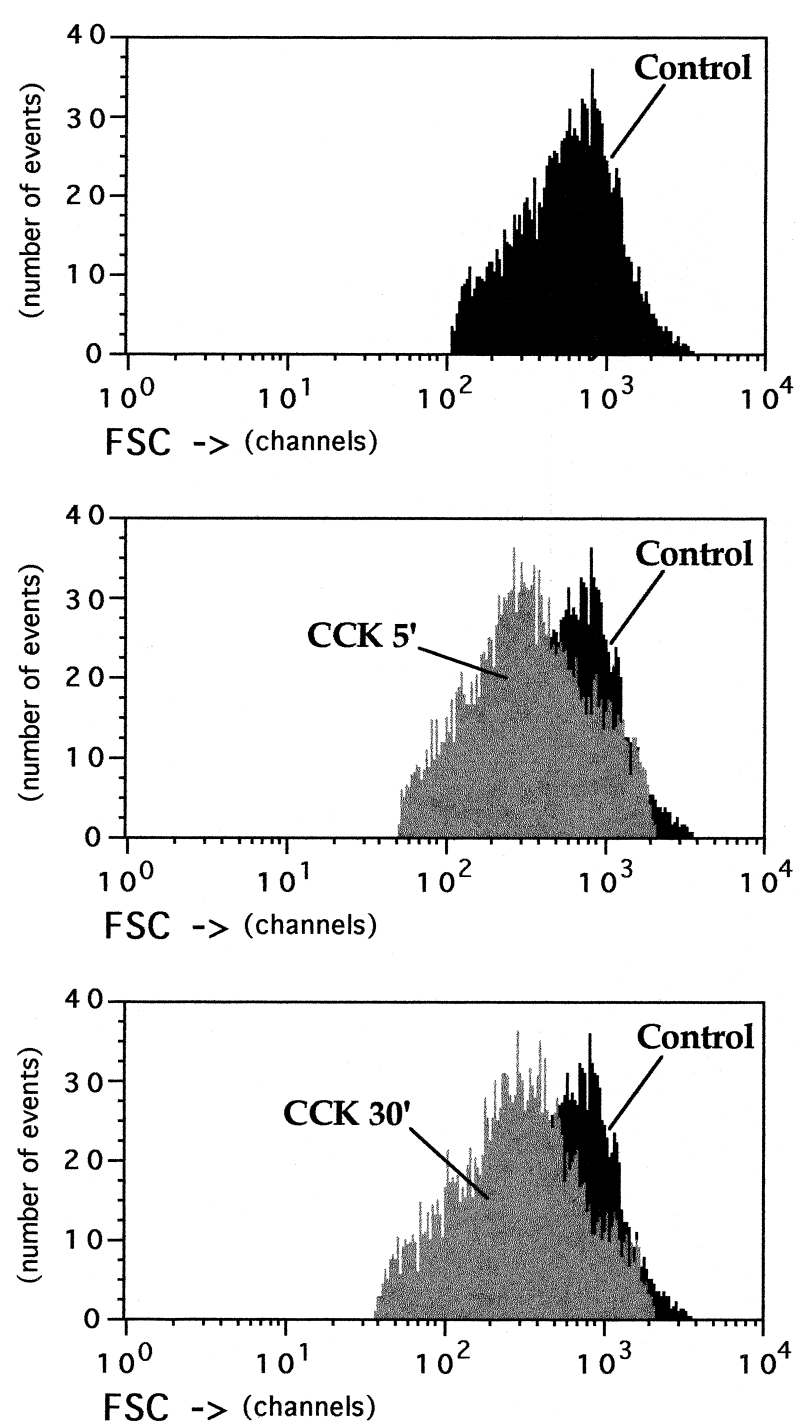

Figure 1 Forward scatter (FSC) distribution of zymogen granules from control rats (black) and rats CCK-stimulated for 5 and 30 min (grey).

\section{Statistical analysis}

esults are expressed as means \pm S.E.M. Statistical analysis of results from the different experimental groups was by analysis of variance (ANOVA) followed by the Scheffé test. Values of $P<0.05$ were considered to be statistically significant in all cases.

\section{Results}

Figure 1 shows a representative example of the zymogen granule distribution according to forward light scatter (FSC). FSC is a parameter directly related to the 


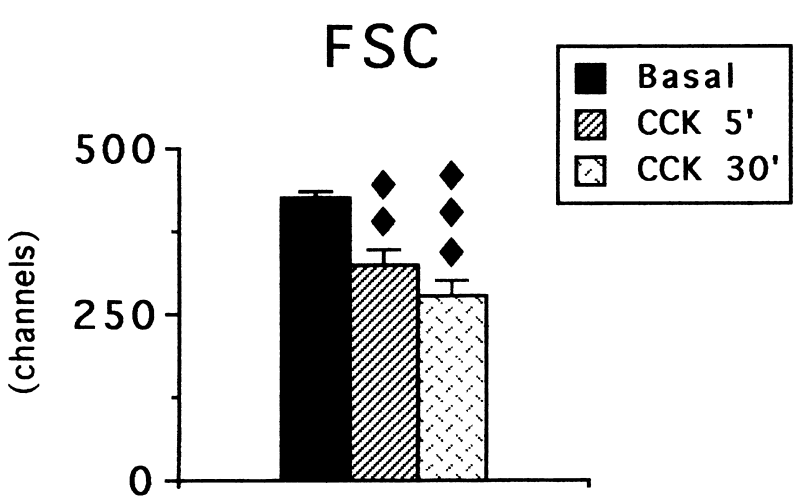

Figure 2 Forward scatter (FSC) of zymogen granules of control rats (basal conditions, $n=12$ animals) and under CCK stimulation for $5 \min (n=12)$ and $30 \min (n=12)$. Values are mean channels \pm S.E.M. (arbitrary units scaled from 0 to 10000 ). ANOVA revealed significant differences: $F(2,23)=13 \cdot 28, P<0 \cdot 001$. Significant differences compared with basal: $\bullet P<0 \cdot 01$, $\leftrightarrow \bullet<0.001$ (Scheffé test).

size - mainly reflecting the cross-sectional area - of the granule (Salzman et al. 1990). As can be seen in the figure, the amount of granules of larger size diminished after CCK infusion, so a shift in the size-frequency distribution towards a lower range was observed under these conditions. As a result of this, the mean value of granule size was significantly decreased in CCK-stimulated rats, from the first 5 min of CCK infusion (Fig. 2).

Figure 3 shows, on a logarithmic scale, a set of representative flow cytometric bivariate distributions of the zymogen granules from control rats and rats stimulated with CCK for $30 \mathrm{~min}$, according to the FSC and amylase or trypsinogen content. Two histograms at the top show the negative fluorescence of the samples. As can be seen, the zymogen granule population displayed a high degree of heterogeneity, indicated by the wide range of staining with specific antisera.

Analysis of the mean values of enzyme content in individual zymogen granules (Fig. 4) revealed no variation in amylase and a significant $(P<0.001)$ decrease in trypsinogen in CCK-stimulated rats over $30 \mathrm{~min}$, at which time the amylase/trypsinogen ratio was, consequently, significantly $(P<0 \cdot 01)$ increased.

The amylase/FSC ratio increased significantly $(P<0 \cdot 001) 5$ and $30 \mathrm{~min}$ after CCK infusion. In addition, CCK stimulation induced an increase in the trypsinogen/ FSC ratio, but statistical significance $(P<0 \cdot 001)$ of the change with respect to basal values was achieved only at 5 min after CCK infusion (Fig. 5).

Table 2 shows the amylase/trypsin ratio in pancreatic juice under basal conditions and with CCK stimulation. A decrease in the enzyme ratio was observed in response to CCK infusion and reached statistical significance $(P<0 \cdot 05)$ after $30 \mathrm{~min}$.

\section{Discussion}

Long-term CCK treatment and protein-enriched diet feeding induce a greater secretion of proteases than of other pancreatic enzymes. This is associated with a modulatory effect of CCK on biosynthesis, acting preferentially on serine proteases (Renaud et al. 1986, Pradel et al. 1993, Lloste et al. 1994, de Dios et al. 1997b). In agreement with previous reports (Dagorn 1978, Grendell et al. 1984), our results also show a non-parallel secretion of enzymes in response to short-term CCK stimulation. Under these conditions, differential release of a previously synthesized product may be taking place. As CCK-stimulated secretion tends to occur via the 'regulated' pathway (Palade 1973), which mainly depends on the exocytosis of zymogen granules, a non-parallel exocytosis should also be considered. Analysis of zymogen granules by flow cytometry shows that they display a large heterogeneity regarding physical properties, enzyme content and glycoprotein membrane composition (Garcia-Montero et al. 1995, de Dios et al. 1997a, Rodriguez et al. 1997), which suggests the possibility of achieving a great diversity of pancreatic responses to specific stimuli.

CCK induces the discharge of larger granules, as deduced by the shift in the size-frequency distribution of granules in rats subjected to CCK infusion. Morphological studies had also reported the same effect after feeding (Ermak \& Rothman 1981, Aughsteen \& Cope 1987) and pharmacological stimulation (Beaudoin et al. 1984). Ermak \& Rothman (1981) suggested that these changes reflected the loss of protein across the membrane, as proposed in the equilibrium hypothesis (Rothman 1975). Previous studies have shown that some cytosolic proteins were secreted in the extracellular medium via a non-classical pathway (Rubartelli et al. 1990, Christmas et al. 1991, Lindstedt et al. 1993). However, these proteins are characterized by a lack of signal sequence in their primary structure. The proteins known to be devoid of signal sequence do not include any of the pancreatic digestive enzymes (Muesch et al. 1990). Therefore, according to the classical scheme, granule content is released by exocytosis (Palade 1973) and the reduction in mean size of the granules may result from a preferential release of the largest zymogen granules in response to CCK.

Zymogen granules remaining in the pancreas $5 \mathrm{~min}$ after CCK infusion showed contents of amylase and trypsinogen similar to those under basal conditions. However, the enzyme/FSC ratio indicated that the two enzymes were more concentrated in each zymogen granule, because the granules were smaller in CCKstimulated rats. In agreement with the findings of Goncz et al. (1995), our results suggest that the concentrations of the intragranular enzyme do not depend on physical limitations, but can be physiologically regulated. The intragranular amylase/trypsinogen ratio revealed that the granules released at the begining of CCK infusion carry a 


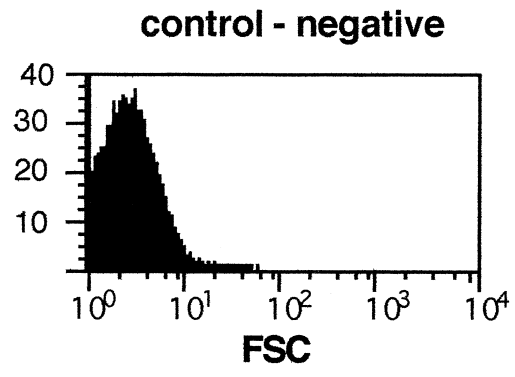

BASAL

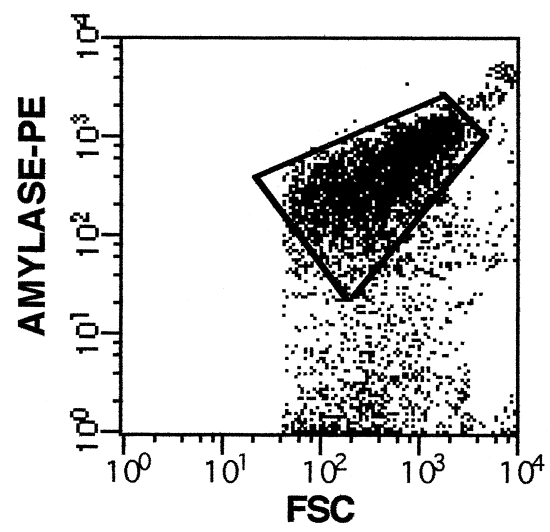

BASAL

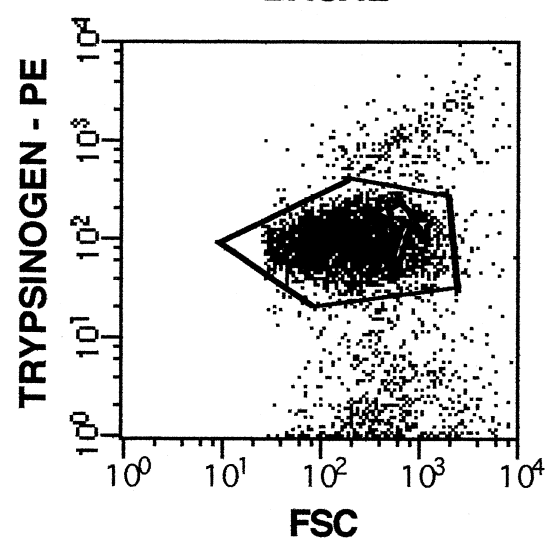

F12 - negative

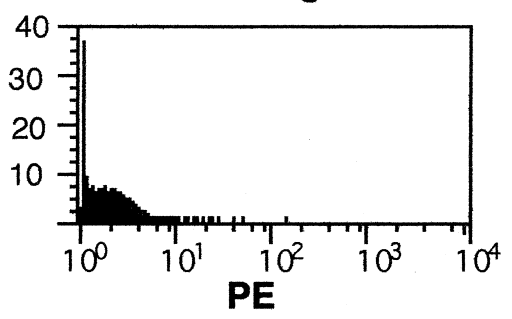

CCK $30 \mathrm{~min}$

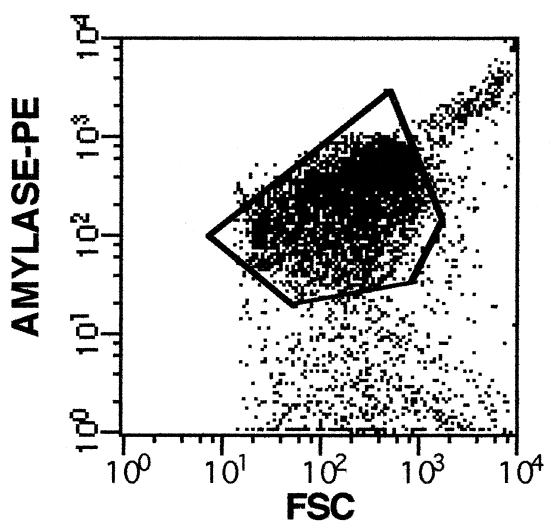

CCK $30 \mathrm{~min}$

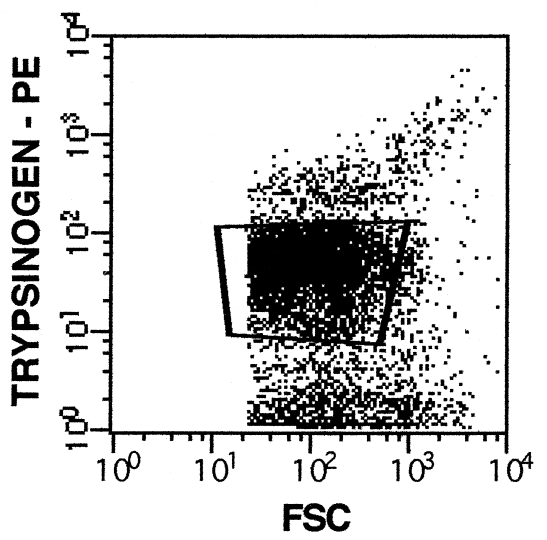

Figure 3 Flow cytometric characterization of zymogen granules. Histograms show the distribution of FSCand fluorescence 2 (Fl2)-negative controls. Dot plots are $\mathrm{log} / \mathrm{log}$ representation of the distribution pattern of zymogen granules from control rats (basal conditions) and from rats stimulated with CCK for $30 \mathrm{~min}$, according to FSC and enzyme (phycoerythrin, PE) fluorescence (FI2).

proportional admixture of both enzymes. Nevertheless, as the infusion continued, CCK preferentially induced the exocytosis of granules with a greater content of trypsinogen than of amylase. In fact, a significant decrease in the quantity of trypsinogen was observed in individual granules $30 \mathrm{~min}$ after CCK infusion. As a consequence, the mean value of the amylase/trypsinogen ratio in single granules was significantly increased. This finding reflects the presence of different types of granules and suggests an ordered partitioning of digestive enzymes within them.

Variation in granule content has been demonstrated by immunocytochemical (Gingras \& Bendayan 1992) and 

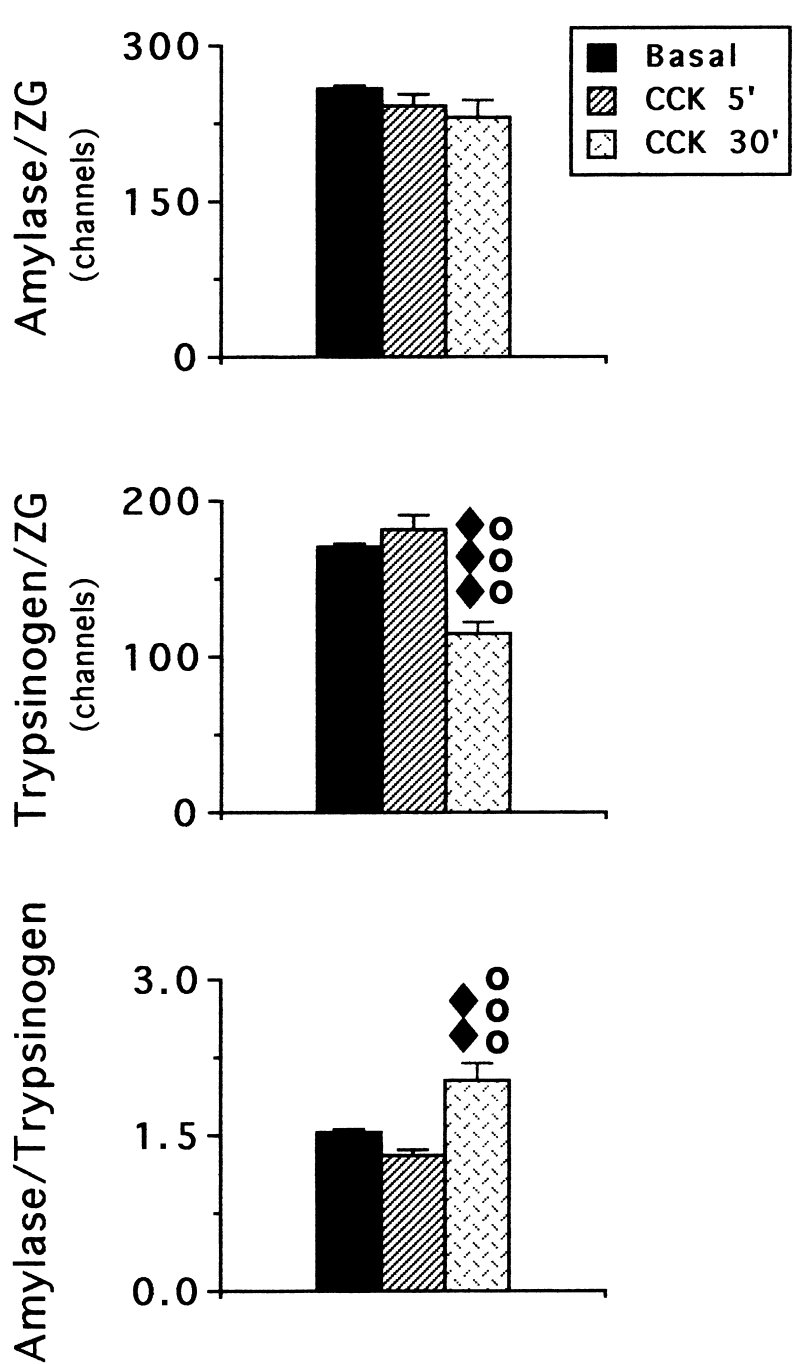

Figure 4 Amylase and trypsinogen content of individual zymogen granules of control rats (basal conditions, $n=10$ animals) and in rats stimulated with CCK for $5 \min (n=6)$ and $30 \min (n=8)$. Values are expressed as mean channels of phycoerythrin fluorescence \pm S.E.M. (arbitrary units scaled from 0 to 10 000). The histogram below represents the mean values of amylase/ trypsinogen ratio in each zymogen granule. ANOVA revealed significant differences in trypsinogen content $(F(2,22)=22 \cdot 51$, $P<0 \cdot 001)$ and in amylase/trypsinogen ratio $(F(2,22)=13 \cdot 00$, $P<0 \cdot 001)$. The Scheffé test revealed significant differences compared with basal values $(\bullet P<0 \cdot 01, \bullet P<0 \cdot 001)$ and compared with 5 min CCK stimulation ( $\left.{ }^{\circ} \mathrm{P}<0 \cdot 001\right)$.

microfluorimetric (Mroz \& Lechene 1986) methods. However, in both studies, a small population of granules was examined. It would be possible to demonstrate multivariate distribution of enzymes, were a large enough sampling of the population to be undertaken. In this respect, flow cytometry provides the possibility of analysing 10000 granules in each test, which offers a high statistical reliability. The use of specific antisera against
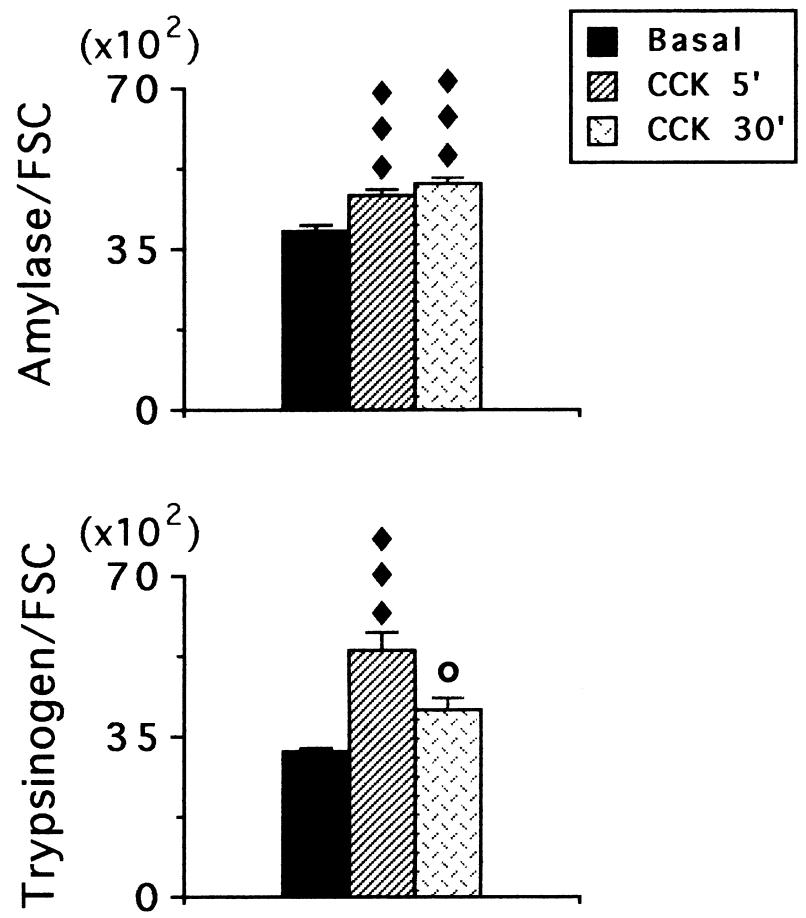

Figure 5 Amylase/FSC ratio and trypsinogen/FSC ratio in zymogen granules of control rats (basal conditions, $n=10$ animals) and in rats stimulated with CCK for $5 \mathrm{~min}(n=6)$ and $30 \mathrm{~min}(n=8)$. Values are expressed as means \pm S.E.M. For both ratios, ANOVA revealed significant differences $(F(2,22)=19 \cdot 60, P<0 \cdot 001$ and $F(2,22)=15 \cdot 82, P<0 \cdot 001$, respectively). The Scheffé test revealed significant differences compared with basal conditions

$(\bullet \bullet P<0 \cdot 001)$ and compared with 5 min CCK stimulation $\left({ }^{\circ} P<0.05\right)$.

intracellular enzymes also provides reliable measurements compared with traditional biochemical methods (de Dios et al. 1997b), with the added advantage that individual granules can be analysed and a high degree of heterogeneity in the zymogen granule population can be observed in terms of their amylase and trypsinogen content (coefficient of variation $>99 \%$ ). The selective release of the different types of granules would explain the nonparallel secretory response of the pancreas to $30 \mathrm{~min}$ of

Table 2 Amylase/trypsin ratio in pancreatic secretion. Values are means \pm S.E.M.; $n=$ number of animals

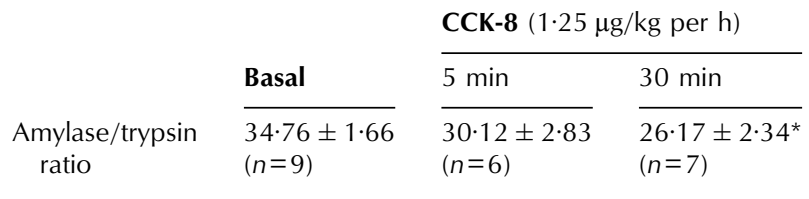

Significant differences: between the three ratios $(F(2,19)=4 \cdot 63, P<0 \cdot 05$; ANOVA); between ratio at CCK $30 \mathrm{~min}$ and basal secretion $\left({ }^{\star} P<0 \cdot 05\right.$, Scheffé test). 
CCK infusion. The significant change in the proportion of amylase and trypsin in pancreatic juice could account for the non-parallel exocytosis of granules, with quantitative rather than qualitative differences regarding their enzyme composition.

Non-parallel exocytosis would also require some mechanism to distinguish among different granule types in order that they be selectively discharged from the cell. Glycoproteins in the zymogen granule membrane seem to be involved in the recognition process between zymogen granules and the inner surface cell membrane (Scheele et al. 1994), and different types of zymogen granule membranes have been reported in the exocrine pancreas of the rat as regards morphology and glycoprotein composition (Beaudoin \& Grondin 1991). Lectin-binding studies carried out recently (de Dios et al. 1997a) demonstrated that glycoconjugates of granule membrane involved in CCK-regulated exocytosis contain large amounts of $\mathrm{N}$-acetyl D-glucosamine. Further studies should be undertaken to find out whether $N$-acetyl D-glucosamineenriched glycoproteins in the zymogen granule membrane are more abundant in those granules with greater proportions of trypsinogen and if it is for this reason that they are preferentially released in response to short-term CCK stimulation.

\section{References}

Adelson JW \& Miller PE 1989 Heterogeneity of the exocrine pancreas. American Journal of Physiology 256 G817-G825.

Aughsteen AA \& Cope GH 1987 Changes in the size and number of secretion granules in the rat exocrine pancreas induced by feeding or stimulation in vitro. Cell Tissue Research 249 427-436.

Beaudoin AR \& Grondin G 1991 Secretory pathways in animal cells: with emphasis on pancreatic acinar cells. Journal of Electron Microscopy Technique 17 51-69.

Beaudoin AR, Grondin G, Filion M \& Lord A 1984 Secretagogues cause a preferential discharge of large size granules in rat pancreas. Canadian Journal of Biochemistry and Cell Biology 62 1288-1292.

Caldwell JB \& Sparrow LG 1970 Partial purification and characterization of two peptide hydrolases from pea seeds. Plant Physiology 57 795798.

Christmas P, Callaway J, Fallon J, Jones J \& Haigler HT 1991 Selective secretion of annexin I, a protein without a signal sequence by the human prostate gland. Journal of Biological Chemistry 266 2499-2507.

Dagorn JC 1978 Non-parallel enzyme secretion from rat pancreas: in vivo studies. Journal of Physiology 280 435-448.

de Dios I, Orfao A, Garcia-Montero AC, Rodriguez AI \& Manso MA 1995 Analysis of isolated zymogen granules from rat pancreas using flow cytometry. Analytical Cellular Pathology 9 215-228.

de Dios I, Rodriguez AI, Garcia-Montero AC, Orfao A \& Manso MA 1997a Cholecystokinin regulates glycoprotein membrane composition of rat pancreatic zymogen granules. Biochimica et Biophysica Acta 1326 131-137.

de Dios I, Rodriguez AI, Garcia-Montero AC, Orfao A \& Manso MA $1997 b$ Enzyme changes in zymogen granules and in pancreatic secretion throughout long-term CCK treatment. Peptides 18 101-110.
De Lisle RC, Schulz I, Tyrakowski T, Haase W \& Hopfer U 1984 Isolation of stable pancreatic zymogen granules. American Journal of Physiology 46 G411-G418.

Ermak TH \& Rothman SS 1981 Zymogen granules of the pancreas decrease in size in response to feeding. Cell Tissue Research 214 $51-66$.

Garcia-Montero AC, de Dios I, Rodriguez AI, Orfao A \& Manso MA 1995 Adrenalectomy induces a decrease in the light scatter properties and amylase content of isolated zymogen granules from rat pancreas as analyzed by flow cytometry. Journal of Endocrinology 147 431-440.

Gingras D \& Bendayan M 1992 Differences in secretory granule content in pancreatic acinar cells from peri-insular and tele-insular regions. Pancreas 7 477-485.

Goncz KK, Behrbing R \& Rothman SS 1995 The protein content and morphogenesis of zymogen granules. Cell Tissue Research $\mathbf{2 8 0}$ 519-530.

Grendell JH, Tseng HC \& Rothman SS 1984 Regulation of digestion. I. Effects of glucose and lysine on pancreatic secretion. American Journal of Physiology 246 G445-G450.

Kachel V, Fellner-Feldegg H \& Menke E 1990 Hydrodynamic properties of flow cytometry instruments. In Flow Cytometry and Sorting, pp 27-45. Eds MR Melamed, T Lindmo \& ML Mendelsohn. New York: J Willey \& Liss.

Lindstedt R, Apodaca G, Barondes SH, Mostov KE \& Leffter H 1993 Apical secretion of a cytosolic protein by Madin-Darby canine kidney cells. Evidence for polarized release of an endogenous lectin by a nonclassical secretory pathway. Journal of Biological Chemistry 268 11750-11757.

Lloste EF, Fiszlewicz M, Gueugneau AM, Tranchant T \& Corring T 1994 Early adaptation of pancreas to protein-enriched diet: role of cholecystokinin and gastrin-releasing peptides. Pancreas 9 624-632.

Manso MA, San Román JI, de Dios I, Garcia LJ \& López MA 1992 Cerulein-induced acute pancreatitis in the rat. Study of pancreatic secretion and plasma VIP and secretin levels. Digestive Diseases and Science 37 364-368.

Manso MA, Garcia-Montero AC, Rodriguez AI, Orfao A \& de Dios I 1997 Hydrocortisone induces an increase of amylase content in individual zymogen granules from rat pancreas. Journal of Steroid Biochemistry and Molecular Biology 62 439-448.

Manso MA, Orfao A, Tabernero MD, Vicente S \& de Dios I 1998 Changes in both the membrane and enzyme content of individual zymogen granules are associated with sodium taurocholate-induced pancreatitis in rats. Clinical Science 94 293-301.

Mroz A \& Lechene C 1986 Pancreatic zymogen granules differ markedly in protein composition. Science 211 871-873.

Muesch A, Hartman E, Rohde K, Rubartelli A, Sitia R \& Rapoport TA 1990 A novel pathway for secretory proteins. Trends in Biochemistry and Sciences 15 86-88.

Noelting G \& Bernfeld P 1948 Sur les enzimes amylolitiques. III. La alpha-amylase, dosage d'activité et contrôle de l'absence de betaamylase. Helvetica Chimica Acta 31 286-290.

Palade GE 1973 Intracellular aspects of the process of protein syntheisis. Science 189 347-358.

Pradel P, Estival A, Seva C, Wickert-Planquart C, Puigserver A, Vaysse N \& Clemente F 1993 Caerulein and gastrin (2-17ds) regulate differently synthesis and secretory enzymes, mRNA levels and cell proliferation in pancreatic acinar cells (AR4-2J). Biochemical Journal $290219-224$.

Rehfeld JF 1989 Cholecystokinin. In Handbook of Physiology. The Gastrointestinal System, Neural and Endocrine Biology, pp 337-358. Bethesda: American Journal of Physiology Society.

Renaud W, Giorgi D, Iovanna J \& Dagorn JC 1986 Regulation of concentrations of mRNA for amylase, trypsinogen I and chymotrypsinogen B in rat pancreas by secretagogues. Biochemical Journal 235 305-308. 
Rodriguez AI, Manso MA, Garcia-Montero AC, Orfao A \& de Dios I 1997 Long-term blockade of cholecystokinin (CCK): effects of L-364,718 (a CCK receptor antagonist) on pancreatic enzyme storage and secretion. Pancreas 15 314-322.

Rothman SS 1975 Protein transport by the pancreas. Science 190 747-753.

Rubartelli A, Cozzolino F, Talio M \& Sitia R 1990 A novel secretory pathway for interleukin-1b, a protein lacking a signal peptide. EMBO Journal 9 1503-1510.

Salzman GC, Singham SB, Jonston RG \& Bohren CF 1990 Light scattering and cytometry. In Flow Cytometry and Sorting, pp 81-107.
Eds MR Melamed, T Lindmo \& ML Mendelsohn. New York: J Willey \& Liss.

Scheele GA, Fukuoka SI \& Freeman SD 1994 Role of the Gp2/THP family of GPI-anchored proteins in membrane trafficking during regulated exocrine secretion. Pancreas 9 139-149.

Williams JA \& Yule DI 1993 Stimulation-secretion coupling in oancreatic acuinar cells. In The Exocrine Pancreas: Biology, Pathology and Disease, pp 167-189. Ed VLW Go. New York: Raven.

Received 26 January 1999

Accepted 8 June 1999 